\title{
IMPLEMENTASI METODE SAW (SIMPLE ADDITIVE WEIGHTING) SEBAGAI PENDUKUNG KEPUTUSAN UNTUK REKOMENDASI HABITAT KELINCI BERBASIS IOT (INTERNET OF THINGS)
}

\author{
Anderias Eko Wijaya*1, Nur Imam Iskandar ${ }^{* 2}$ \\ Program Studi Teknik Informatika, STMIK Subang ${ }^{* 1}$ \\ Program Studi Teknik Informatika, STMIK Subang \#2 \\ E-mail: ekowjy09@yahoo.com ${ }^{* 1}$,nurimamiskandar@gmail.com ${ }^{\sharp 2}$
}

\begin{abstract}
ABSTRAK
Kelinci adalah hewan mamalia dari famili leporidae (pemakan tumbuhan hijau) yang dapat ditemukan di banyak bagian bumi. Kelinci sangat rentan terhadap perubahan temperature. Temperature atau suhu sangat mempengaruhi metabolisme tubuh kelinci. Temperature ideal bagi kelinci adalah berada pada kisaran 60 - 65oF atau sama dengan 15.5 - 18.3oC yang diketahui sebagai suhu "comfort zone" bagi kelinci. Tingkat stres panas pada kelinci sangat tinggi di daerah tropis sehing ga mengurangi produktivitas kelinci. Dengan adanya sistem yang peneliti buat ini dapat mempermudah dalam menentukan tempat yang cocok untuk dijadikan sebagai habitat kelinci dengan bantuan jaringan sistem Internet of Things dan mengurangi tingkat kegagalan dalam memelihara kelinci serta implementasi node-red sebagai platform untuk mennampilkan hasil keputusan perhitungan metode.

Sistem yang diterapkan menggunakan metode perangkingan SAW (Simple Additive Weight) atau biasa disebut dengan metode terbobot ini dengan menggunakan tiga parameter diantaranya: suhu; kelembaban; cahaya. Namun data harus melalui perhitungan yang menghasilkan satu nilai dari masing-masing lokasi yang kemudian di normalisasikan sehingga mendapatkan keputusan dengan penjumlahan antara perkalian normalisasi dengan bobot.

Implementasi Metode SAW (Simple Additive Weighting) Sebagai Pendukung Keputusan Untuk Rekomendasi Habitat Kelinci Berbasis Iot (Internet Of Things) telah berhasil diterapkan. Sehingga dapat melakukan perangkingan lokasi habitat kelinci berdasarkan parameter suhu, kelembaban, cahaya. Namun meskipun sistem ini dibangun berbasis IoT namun belum bisa diakses secara publik atau masih berbasis localhost.
\end{abstract}

\section{Kata Kunci : Internet of Things, Kelinci, Node-Red, Simple Additive Weighting}

\begin{abstract}
Rabbits are mammals from the family leporidae (green plant eaters) which can be found in many parts of the earth. Rabbits are very susceptible to temperature changes. Temperature greatly affects the rabbit's body metabolism. Temperature ideal for rabbits is in the range of $60-650 F$ or equal to 15.5 - 18.30C temperature is known as "comfort zone" for rabbits. The level of heat stress in rabbits is very high in the tropics thereby reducing rabbit productivity. With a system that researchers can make it easier to determine the suitable place to serve as a rabbit habitat with Internet of Things system network, and reduce the failure rate in keeping rabbits as well as the implementation of the node-ed as a platform to display the results of the calculation method of the decision.

The system is applied using the SAW (Simple Additive Weight) ranking method or commonly called this weighted method by using three parameters including: temperature; humidity; light. However, the data must go through a calculation that generates a value of each location then normalize to get a decision by the sum of the multiplication of normalization with weights.

Implementation Methods of SAW (Simple Additive weighting) as Decision Support Habitat For Rabbits Recommendation Based Iot (Internet Of Things) has been successfully applied. So that it can rank rabbit habitat locations based on parameters of temperature, humidity, light. However, although the system is built based IOT but has not publicly accessible or still based on localhost.
\end{abstract}

\section{Kata Kunci : Internet of Things, Node-Red, Rabbits, Simple Additive Weighting}




\section{Pendahuluan}

\section{1 Latar Belakang}

Kelinci adalah hewan mamalia dari famili Leporidae (pemakan tumbuhan hijau), yang dapat ditemukan di banyak bagian bumi. Dulunya, hewan ini adalah hewan liar yang hidup di Afrika hingga ke daratan Eropa. Pada perkembangannya, tahun 1912 Kelinci diklasifikasikan dalam ordo Lagomorpha. Ordo ini dibedakan menjadi dua famili, yakni Ochtonidae (jenis pika yang pandai bersiul) dan Leporidae (termasuk di dalamnya jenis kelinci danterwelu)[1].

Kelinci sangat rentan terhadap perubahan temperature. Temperature atau suhu udara sangat mempengaruhi proses metabolisme tubuh kelinci. Konsumsi kelinci juga sangat dipengaruhi oleh suhu lingkungan. Ketika suhu lingkungan melebihi zona tubuh comfort (zona nyaman), maka kelinci cenderung akan mengurangi konsumsi dan memperbanyak minum. Ketika suhu lingkungan berada di bawah zona nyaman bagi kelinci, maka kelinci cenderung memperbanyak konsumsi pakan untuk dapat mempertahankan suhu tubuhnya.

Temperatur ideal bagi kelinci adalah berada pada kisaran $60-65^{\circ} \mathrm{F}$ atau sama dengan $15.5-$ $18.3^{\circ} \mathrm{C}$ yang diketahui sebagai temperature "comfort zone" bagi kelinci. Kelinci lebih tahan pada cekaman suhu dingin jika dibandingkan dengan suhu panas seperti di daerah Indonesia yang merupakan daerah tropis yang suhu udaranya relative tinggi[2].

Kelinci sudah cukup lama dikenal oleh peternak dan telah beradaptasi dengan lingkungan tropis Indonesia adalah kelinci-kelinci impor dari berbagai negara di Eropa dan Amerika[3]. Kehidupan kelinci memiliki dimensi sosial yang kuat sehingga ia akan merasa tertekan manakala terpisahkan dari lingkungannya yang tadinya nyaman berubah ke lingkungan yang tak nyaman[4]. Suhu udara yang panas menyebabkan kelinci banyak mengonsumsi air dan mengurangi kegiatan makan sehingga produktivitas kelinci berkurang. Karakteristik pakan kelinci yang hidup di daerah tropis hendaknya besifat sedikit kuantitasnya namun tinggi akan nilai nutrisi sehingga dapat mengimbangi kebutuhan kelinci terhadap rasio pakan dan minum kelinci[2].

Selain stress karena cekaman panas, fluktuasi suhu juga dapat menyebabkan gangguan pencernaan pada kelinci. Perubahan suhu harian dari tingkat panas ke dingin secara fluktuasi dapat merubah pola makan kelinci. Pola makan yang berubah drastis berdampak pada perubahan pola fermentasi pakan di dalam saluran pencernaan khususnya pada sekum. Sebagai akibatnya, maka terjadi konsumsi karbohidrat yang berlebih yang menyebabkan isi sekum didominasi oleh karbohidrat yang mudah difermentasi[2].

Bakteri yang hidup di dalam tubuh manusia merupakan koloni bakteri yang bermanfaat. Peran mikrobioma adalah membantu mencerna makanan, mengatur sistem imun, dan perlindungan terhadap bakteri pathogen[5]. Bakteri pathogen cenderung lebih memilih bahan makanan yang mudah difermentasi (karbohidrat), sehingga hal tersebut dapat mendorong perkembangan (proliferasi) bakteri pathogen di dalam saluran pencernaan. Populasi bakteri pathogen yang meningkat di saluran pencernaan dapat membahayakan induk inangnya yaitu kelinci itu sendiri dan dapat menyebabkan kematian.

Solusi pemeliharaan kelinci yang terbaik adalah dengan menjaga lingkungan hidup kelinci agar tetap nyaman. Hal tersebut bisa dilihat dari model atap atau pun kandang dan disertai dengan vegetasi lingkungan kandang. Pepohonan disekitar kandang sangat berperan penting dalam menjaga fluktuasi perubahan suhu yang drastis. Sirkulasi kandang dari tipe atap monitor dan model kandang terbuka dengan dibatasi naungan vegetasi penghalang angin dapat menjadi pilihan dalam membangun kandang kelinci di daerah tropis.

Tujuan dari penelitian ini adalah untuk menentukan lokasi yang sesuai dijadikan sebagai habitat kelinci, Sedangkan tujuan yang akan dicapai dalam penelitian ini adalah menerapkan IoT sebagai sistem pendukung keputusan habitat kelinci dan menentukan tempat yang cocok dijadikan sebagai habitat kelinci. Manfaat yang diinginkan adalah mengurangi tingkat kegagalan dalam memelihara kelinci, memudahkan peternak dalam menentukan tempat bagi kelinci berkembang biak dengan subur dan memudahkan peternak dalam mencari habitat yang sesuai untuk dijadikan tempat tinggal kelinci.

\subsection{Metodologi Penelitian}

Metodologi penelitian yang digunakan sebagai berikut:

1. Sistem Pendukung Keputusan

Decision Support System (DSS) dalam bahasa Indonesia biasa disebut sebagai sistem pendukung keputusan merupakan bagian dari sistem informasi berbasis komputer yang digunakan untuk mendukung bisnis atau kegiatan pengambilan keputusan dalam suatu organisasi atau perusahaan.

DSS termasuk kedalam sistem yang berbasis pengetahuan. Rancangan DSS yang baik adalah sebuah sistem berbasis software interaktif yang ditujukan untuk mampu membantu pengambil 
keputusan mengkompilasi informasi yang berguna dari kombinasi data-data yang masih mentah, dokumen dan pengetahuan pribadi atau model bisnis untuk mengidentifikasi dan memecahkan masalah serta membuat keputusan.

Tujuan dari DSS itu sendiri adalah melayani manajemen, operasi, tingkat perencanaan organisasi, meningkatkan efektifitas dalam pengambilan keputusan dan membantu orang membuat keputusan tentang masalah yang mungkin berubah dengan cepat dan tidak mudah diselesaikan[6].

2. Analisa dan Perancangan Sistem

Mengkaji hasil studi literatur, hasil survei lapangan, dan menganalis yang dibutuhkan untuk melakukan perancangan awal aplikasi yang akan dibuat, sehingga akan dihasilkan desain antarmuka dan proses yang untuk diimplementasikan.

3. Uji Coba dan Evaluasi Aplikasi

Pada tahap ini sistem yang telah dibuat ini akan dilakukan beberapa skenario uji coba dan dievaluasi untuk kelayakan pemakaian sistem.

\section{Tinjauan Pustaka}

\subsection{Sistem Pendukung Keputusan}

Sistem pendukung keputusan (SPK) adalah salah satu cara mengorganisir informasi (melibatkan penggunaan basis data) yang dimaksudkan untuk digunakan dalam membuat keputusan. SPK dirancang untuk pendekatan menyelesaikan masalah para pembuat keputusan dan kebutuhankebutuhan aplikasi, tetapi tidak untuk menggantikan keputusan maupun membuat suatu keputusan untuk pengguna[7].

\subsection{Definisi Internet Of Things}

Internet of Things (IOT) adalah struktur dimana objek, orang disediakan dengan identitas eksklusif dan kemampuan untuk pindah data melalui jaringan tanpa memerlukan dua arah antara manusia ke manusia yaitu sumber ke tujuan atau interaksi manusia ke komputer. Internet of Things merupakan perkembangan keilmuan yang sangat menjanjikan untuk mengoptimalkan kehidupan berdasarkan sensor dan sensor ini mengkonversi data fisik mentah menjadi sinyal digital dan mengirimkan mereka ke pusat control[8].

\subsection{Simple Additive Weighting}

Metode SAW adalah salah satu metode dari Multiple Attribute Decision Making (FMADM) yang paling sering digunakan. Metode ini merupakan dasar dari sebagian metode FMADM yang seperti AHP dan PROMETHEE yang menghitung nilai akhir alternatif yang diberikan. Metode SAW sering juga dikenal istilah metode penjumlahan terbobot[9][10].

Konsep dasar metode SAW adalah mencari penjumlahan terbobot dari rating kinerja pada setiap alternatif pada semua atribut. Metode SAW membutuhkan proses normalisasi matriks keputusan (X) ke suatu skala yang dapat membandingkan dengan semua rating alternatif yang ada. Metode ini merupakan metode yang paling terkenal dan paling banyak digunakan dalam menghadapi situasi Multiple Attribute Decision Making (MADM). MADM itu sendiri merupakan suatu metode yang digunakan untuk mencari alternatif dengan kriteria tertentu.

Metode Simple Additive Weighting (SAW) ini mengharuskan pembuat keputusan menentukan bobot bagi setiap atribut. Skor total untuk alternatif diperoleh dengan menjumlahkan seluruh hasil perkalian antara rating (yang dapat dibandingkan lintas atribut) dan bobot tiap atribut. Rating tiap atribut haruslah bebas dimensi dalam arti telah melewati proses normalisasi matriks sebelumnya.

Langkah penyelesaian Simple Additive Weighting (SAW) sebagai berikut[11]:

a. Menentukan kriteria-kriteria yang akan dijadikan acuan dalam pengambilan keputusan, yaitu Ci.

b. Menentukan rating kecocokan setiap alternatif pada setiap kriteria.

c. Membuat matriks keputusan berdasarkan kriteria (Ci), kemudian melakukan normalisasi matriks berdasarkan persamaan yang disesuaikan dengan jenis atribut (atribut keuntungan ataupun atribut biaya) sehingga diperoleh matriks normalisasi R.

d. Hasil akhir diperoleh dari proses perangkingan yaitu penjumlahan dari perkalian matriks ternormalisasi $\mathrm{R}$ dengan vektor bobot sehingga diperoleh nilai terbesar yang dipilih sebagai alternatif terbaik (Ai) sebagai solusi.

Formula untuk melakukan normalisasi tersebut adalah:

Jika $\mathrm{j}$ adalah atribut keuntungan (benefit)

Jika $\mathrm{j}$ adalah atribut biaya (cost) 


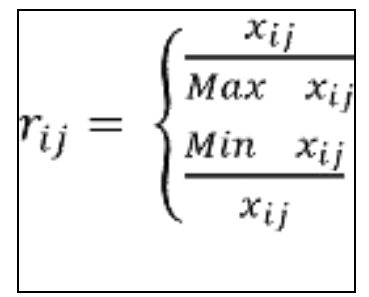

Gambar 2. 1 Formula Normalisasi

Dimana:

- Rij = Rating kinerja ternormalisasi

- Max ij = Nilai maksimum dari setiap baris dan kolom

- Min ij = Nilai minimum dari setiap baris dan kolom

- Xij = Baris dan kolom dari matriks

Dengan Rij adalah rating kinerja ternormalisasi adri alternatif Ai pada atribut $\mathrm{Cj} ; \mathrm{i}=1,2, \ldots, \mathrm{m}$ dan $\mathrm{j}=$ $1,2, \ldots, \mathrm{n}$.

Nilai referensi untuk setiap alternatif (Vi) diberikan sebagai:

$$
V_{i}=\sum_{j=1}^{n} W_{j} r_{i j}
$$

Dimana:

$-\mathrm{Vi} \quad=$ Nilai akhir dari alternatif

$-\mathrm{Wj} \quad=$ Bobot yang telah ditentukan

$-\mathrm{Rij} \quad=$ Normalisasi matriks

Nilai Vi yang lebih besar mengindikasikan bahwa alternatif Ai lebih terpilih[5].

\subsection{Kelinci}

Kelinci adalah hewan mamalia dari famili Leporidae (pemakan tumbuhan hijau), yang dapat ditemukan di banyak bagian bumi. Dulunya, hewan ini adalah hewan liar yang hidup di Afrika hingga ke daratan Eropa. Pada perkembangannya, tahun 1912 Kelinci diklasifikasikan dalam ordo Lagomorpha. Ordo ini dibedakan menjadi dua famili, yakni Ochtonidae (jenis pika yang pandai bersiul) dan Leporidae (termasuk di dalamnya jenis kelinci danterwelu)[1].

Kelinci sangat rentan terhadap perubahan temperature. Temperature atau suhu udara sangat mempengaruhi proses metabolisme tubuh kelinci. Konsumsi kelinci sangat dipengaruhi oleh suhu lingkungan. Ketika suhu lingkungan melebihi zona tubuh comfort (zona nyaman), maka kelinci cenderung akan mengurangi konsumsi dan memperbanyak minum. Ketika suhu lingkungan berada di bawah zona nyaman bagi kelinci, maka kelinci cenderung memperbanyak konsumsi pakan untuk dapat mempertahankan suhu tubuhnya.

Temperatur ideal bagi kelinci adalah berada pada kisaran $60-65^{\circ} \mathrm{F}$ atau sama dengan $15.5-$ $18.3^{\circ} \mathrm{C}$ yang diketahui sebagai temperature "comfort zone" bagi kelinci. Kelinci lebih tahan pada cekaman suhu dingin jika dibandingkan dengan suhu panas seperti di daerah Indonesia yang merupakan daerah tropis yang suhu udaranya relative tinggi[2].

Pengaruh lingkungan terutama suhu udara sangat mempengaruhi performansi kelinci yang hidup di daerah tropis. Tingkat stress panas pada kelinci sangat tinggi di daerah tropis sehingga mengurangi produktifitas kelinci. Suhu udara yang panas menyebabkan kelinci banyak mengonsumsi air dan mengurangi kegiatan makan sehingga produktivitas kelinci berkurang. Karakteristik pakan kelinci yang hidup di daerah tropis hendaknya besifat sedikit kuantitasnya namun tinggi akan nilai nutrisi sehingga dapat mengimbangi kebutuhan kelinci terhadap rasio pakan dan minum kelinci.

Fluktuasi suhu lingkungan harian dapat menyebabkan penyakit pada kelinci. Selain stress karena cekaman panas, fluktuasi suhu juga dapat menyebabkan gangguan pencernaan pada kelinci. Enteritis merupakan penyakit pencernaan yang sering terjadi pada kelinci anakan dan menyebabkan tingkat mortalitas kelinci tinggi. Perubahan suhu harian dari tingkat panas ke dingin secara fluktuasi dapat merubah pola makan kelinci. Pola makan yang berubah drastis berdampak pada perubahan pola fermentasi pakan di dalam saluran pencernaan khususnya pada sekum. Sebagai akibatnya, maka terjadi konsumsi karbohidrat yang berlebih yang menyebabkan isi sekum didominasi oleh karbohidrat yang mudah difermentasi. 
Bakteri pathogen cenderung lebih memilih bahan makanan yang mudah difermentasi (karbohidrat), sehingga hal tersebut dapat mendorong perkembangan (proliferasi) bakteri pathogen di dalam saluran pencernaan. Populasi bakteri pathogen yang meningkat di saluran pencernaan dapat membahayakan induk inangnya yaitu kelinci itu sendiri dan dapat menyebabkan kematian.

Solusi pemeliharaan kelinci yang terbaik adalah dengan menjaga lingkungan hidup kelinci agar tetap nyaman. Hal tersebut bisa dilihat dari model atap atau pun kandang dan disertai dengan vegetasi lingkungan kandang. Pepohonan disekitar kandang sangat berperan penting dalam menjaga fluktuasi perubahan suhu yang drastis. Sirkulasi kandang dari tipe atap monitor dan model kandang terbuka dengan dibatasi naungan vegetasi penghalang angin dapat menjadi pilihan dalam membangun kandang kelinci di daerah tropis.

\section{$2.5 \quad$ Node-RED}

Node-RED adalah sebuah tool berbasis browser untuk membuat aplikasi Internet of Things (IoT) yang mana lingkungan pemrograman visualnya mempermudah penggunanya untuk membuat aplikasi sebagai "flow". Lanskap bahasa pemrograman sangatlah luas dan meliput berbagai jenis gaya dan paradigma pemrograman. Bahasa imperatif berorientasi objek saat ini menguasai dunia pemrograman, namun begitu sebetulnya ada alternatif untuk pengembangan atau produksi software dan juga untuk membuat prototipe ide dengan cepat[12].

Flow ini terbentuk dari node-node yang saling berhubungan dimana tiap node melakukan tugas tertentu. Walaupun Node-RED di desain untuk Internet of Things (IoT), ia juga dapat digunakan untuk keperluan umum dan untuk berbagai jenis macam aplikas[13].

Node-RED menyediakan berbagai jenis node yang dapat membuat membuat developer langsung menjadi produktif, seperti:

1. Menampilkan input node dan output node yang mana mengizinkan subskripsi dan tanda terima dari topik MQ Telemetry Transport (MQTT) dan keluaran dari topik MQTT ke sebuah broker.

2. Mengembangan layanan web melalui permintaan HTTP (beserta pembuatan balasan HTTP); dan TCP level rendah dah layanan User Datagram Protocol yang dapat membuat server, menerima input, dan menghasilkan output.

\section{Analisis dan Pembahasan}

\subsection{Deskripsi Sistem}

Rancangan sistem pendukung keputusan untuk rekomendasi habitat kelinci berbasis web menggunakan nodemcu ESP8266, DHT11 untuk suhu dan kelembaban, LDR untuk mengukur tingkat intensitas cahaya. Sistem juga berbasis Internet of Things dengan menggunakan splatform Node-Red.

\subsection{Implementasi Metode SAW}

Dalam mengimplementasikan metode Simple Additive Weighting dalam menentukan menentukan lokasi habitat kelinci ini maka hal pertama yang harus dilakukan yaitu menghitung bobot setiap kriteria untuk mencari alternatif yang diinginkan. berikut:

Pada penelitian ini alternatif tema ditandai dengan A1 sampai A10, dengan uraian sebagai
A1 = TONGGOH1
$\mathrm{A} 2=\mathrm{TONGGOH} 2$
A4 = GIRANG1
A5 = GIRANG2
A3 $=$ TONGGOH3
A7 $=$ HILIR1
A8 $=$ HILIR2
A6 = GIRANG3
A9 $=$ HILIR3
A10 = GIRANG4

Indikator ketentuan nilai ditandai dengan C1 sampai C3 dengan uraian sebagai berikut:

\begin{tabular}{|c|c|c|c|c|}
\hline \multicolumn{2}{|c|}{$\mathrm{C} 1=\mathrm{Suhu}$} & $\mathrm{C} 2=$ Kelembaban & \multicolumn{2}{|c|}{ C3 = Cahaya } \\
\hline \multirow{2}{*}{ No } & \multirow{2}{*}{ ALTERNATIF } & \multicolumn{3}{|c|}{ KRITERIA } \\
\hline & & $\mathrm{C} 1$ & $\mathrm{C} 2$ & C3 \\
\hline 1 & A1 & 34 & 46 & 45,13043478 \\
\hline 2 & $\mathrm{~A} 2$ & 32 & 58,03703704 & 46,2962963 \\
\hline 3 & A3 & 32 & 56,82978723 & 39,63829787 \\
\hline 4 & A4 & 42 & 32 & 33,86046512 \\
\hline 5 & A5 & 43 & 30 & 43,87234043 \\
\hline 6 & A6 & 43 & 31 & 46,04255319 \\
\hline 7 & A7 & 38 & 28 & 44,86046512 \\
\hline 8 & A8 & 32 & 35,95238095 & 94,76190476 \\
\hline
\end{tabular}




\begin{tabular}{|l|l|l|l|l|}
\hline 9 & A9 & 34 & 31 & 91,51219512 \\
\hline 10 & A10 & 37 & 24,76190476 & 50,71428571 \\
\hline
\end{tabular}

$$
X=\left\{\begin{array}{ccc}
34 & 46,000 & 45,130 \\
32 & 53,037 & 46,296 \\
32 & 56,826 & 39,638 \\
42 & 32 & 33,860 \\
43 & 30 & 43,872 \\
43 & 31 & 46,042 \\
38 & 28 & 44,860 \\
32 & 35,952 & 94,761 \\
34 & 31,000 & 91,512 \\
37 & 24,762 & 50,711
\end{array}\right\}
$$

Normalisasi Matriks X menggunakan persamaan 1:

- Alternatif A1

$$
\begin{aligned}
& r 11=\frac{34}{\operatorname{MIN}(34 ; 32 ; 32 ; 42 ; 43 ; 43 ; 38 ; 32 ; 34 ; 37)}=0,941176471 \\
& r 12=\frac{46}{\operatorname{MAX}(46 ; 58,03 ; 56,82 ; 32 ; 30 ; 31 ; 28 ; 35,95 ; 31 ; 24,76)}=0,79259732 \\
& r 13=\frac{45,13}{\operatorname{MIN}(45,13 ; 46,29 ; 39,63 ; 33,86 ; 43,87 ; 46,04 ; 44,86 ; 94,76 ; 91,51 ; 50,71)}=0,750280056
\end{aligned}
$$

\section{- $\quad$ Alternatif A2}

$$
\begin{aligned}
& r 21=\frac{32}{\operatorname{MIN}(34 ; 32 ; 32 ; 42 ; 43 ; 43 ; 38 ; 32 ; 34 ; 37)}=1 \\
& r 22=\frac{58,03}{\operatorname{MAX}(46 ; 58,03 ; 56,82 ; 32 ; 30 ; 31 ; 28 ; 35,95 ; 31 ; 24,76)}=1 \\
& r 23=\frac{46,29}{\operatorname{MIN}(45,13 ; 46,29 ; 39,63 ; 33,86 ; 43,87 ; 46,04 ; 44,86 ; 94,76 ; 91,51 ; 50,71)}=0,731386047
\end{aligned}
$$

\section{- $\quad$ Alternatif A3}

$$
\begin{aligned}
& r 31=\frac{32}{\operatorname{MIN}(34 ; 32 ; 32 ; 42 ; 43 ; 43 ; 38 ; 32 ; 34 ; 37)}=1 \\
& r 32=\frac{56,82}{\operatorname{MAX}(46 ; 58,03 ; 56,82 ; 32 ; 30 ; 31 ; 28 ; 35,95 ; 31 ; 24,76)}=0,979198631 \\
& r 33=\frac{39,63}{\operatorname{MIN}(45,13 ; 46,29 ; 39,63 ; 33,86 ; 43,87 ; 46,04 ; 44,86 ; 94,76 ; 91,51 ; 50,71)}=0,854236103
\end{aligned}
$$

\section{- $\quad$ Alternatif A4}

$$
\begin{aligned}
r 41 & =\frac{42}{M I N(34 ; 32 ; 32 ; 42 ; 43 ; 43 ; 38 ; 32 ; 34 ; 37)}=0,761904762 \\
r 42 & =\frac{32}{\operatorname{MAX}(46 ; 58,03 ; 56,82 ; 32 ; 30 ; 31 ; 28 ; 35,95 ; 31 ; 24,76)}=0,551372049 \\
r 43 & =\frac{33,86}{\operatorname{MIN}(45,13 ; 46,29 ; 39,63 ; 33,86 ; 43,87 ; 46,04 ; 44,86 ; 94,76 ; 91,51 ; 50,71)}=1
\end{aligned}
$$

\section{- $\quad$ Alternatif A5}

$$
r 51=\frac{43}{\operatorname{MIN}(34 ; 32 ; 32 ; 42 ; 43 ; 43 ; 38 ; 32 ; 34 ; 37)}=0,744186047
$$




$$
\begin{aligned}
& r 52=\frac{30}{\operatorname{MAX}(46 ; 58,03 ; 56,82 ; 32 ; 30 ; 31 ; 28 ; 35,95 ; 31 ; 24,76)}=0,516911295 \\
& r 53=\frac{43,87}{\operatorname{MN}(45,13 ; 46,29 ; 39,63 ; 33,86 ; 43,87 ; 46,04 ; 44,86 ; 94,76 ; 91,51 ; 50,71)}=0,771795277
\end{aligned}
$$

\section{- $\quad$ Alternatif A6}

$$
\begin{aligned}
& r 61=\frac{43}{\operatorname{MIN}(34 ; 32 ; 32 ; 42 ; 43 ; 43 ; 38 ; 32 ; 34 ; 37)}=0,744186047 \\
& r 62=\frac{31}{\operatorname{MAX}(46 ; 58,03 ; 56,82 ; 32 ; 30 ; 31 ; 28 ; 35,95 ; 31 ; 24,76)}=0,534141672 \\
& r 63=\frac{46,04}{\operatorname{MIN}(45,13 ; 46,29 ; 39,63 ; 33,86 ; 43,87 ; 46,04 ; 44,86 ; 94,76 ; 91,51 ; 50,71)}=0,735416756
\end{aligned}
$$

\section{- $\quad$ Alternatif A7}

$$
\begin{aligned}
& r 71=\frac{38}{\operatorname{MIN}(34 ; 32 ; 32 ; 42 ; 43 ; 43 ; 38 ; 32 ; 34 ; 37)}=0,842105263 \\
& r 72=\frac{28}{\operatorname{MAX}(46 ; 58,03 ; 56,82 ; 32 ; 30 ; 31 ; 28 ; 35,95 ; 31 ; 24,76)}=0,482450542 \\
& r 73=\frac{44,86}{\operatorname{MIN}(45,13 ; 46,29 ; 39,63 ; 33,86 ; 43,87 ; 46,04 ; 44,86 ; 94,76 ; 91,51 ; 50,71)}=0,754795231
\end{aligned}
$$

\section{- $\quad$ Alternatif A8}

$$
\begin{aligned}
& r 81=\frac{32}{\operatorname{MIN}(34 ; 32 ; 32 ; 42 ; 43 ; 43 ; 38 ; 32 ; 34 ; 37)}=1 \\
& r 82=\frac{35,95}{\operatorname{MAX}(46 ; 58,03 ; 56,82 ; 32 ; 30 ; 31 ; 28 ; 35,95 ; 31 ; 24,76)}=0,61947306 \\
& r 83=\frac{94,76}{\operatorname{MNN}(45,13 ; 46,29 ; 39,63 ; 33,86 ; 43,87 ; 46,04 ; 44,86 ; 94,76 ; 91,51 ; 50,71)}=0,357321491
\end{aligned}
$$

- Alternatif A9

$$
\begin{aligned}
& r 91=\frac{34}{\operatorname{MIN}(34 ; 32 ; 32 ; 42 ; 43 ; 43 ; 38 ; 32 ; 34 ; 37)}=0,941176471 \\
& r 92=\frac{31}{\operatorname{MAX}(46 ; 58,03 ; 56,82 ; 32 ; 30 ; 31 ; 28 ; 35,95 ; 31 ; 24,76)}=0,534141672 \\
& r 93=\frac{91,51}{\operatorname{MIN}(45,13 ; 46,29 ; 39,63 ; 33,86 ; 43,87 ; 46,04 ; 44,86 ; 94,76 ; 91,51 ; 50,71)}=0,370010413
\end{aligned}
$$

\section{- Alternatif A10}

$$
\begin{aligned}
& r 101=\frac{37}{\operatorname{MIN}(34 ; 32 ; 32 ; 42 ; 43 ; 43 ; 38 ; 32 ; 34 ; 37)}=0,86486,4865 \\
& r 102=\frac{24,76}{\operatorname{MAX}(46 ; 58,03 ; 56,82 ; 32 ; 30 ; 31 ; 28 ; 35,95 ; 31 ; 24,76)}=0,426656942 \\
& r 103=\frac{50,71}{\operatorname{MIN}(45,13 ; 46,29 ; 39,63 ; 33,86 ; 43,87 ; 46,04 ; 44,86 ; 94,76 ; 91,51 ; 50,71)}=0,66767114
\end{aligned}
$$

Mencari alternatif menggunakan persamaan 2:

$\mathrm{V} 1=(0,941176471 \times 0,4)+(0,79259732 \times 0,4)+(0,750280056 \times 0,2)=0,843565527$

$\mathrm{V} 2=(1 \times 0,4)+(1 \times 0,4)+(0,731386047 \times 0,2)=0,946277209$

$\mathrm{V} 3=(1 \times 0,4)+(0,979198631 \times 0,4)+(0,854236103 \times 0,2)=0,962526673$

$\mathrm{V} 4=(0,761904762 \times 0,4)+(0,551372049 \times 0,4)+(1 \times 0,2)=0,725310724$

$\mathrm{V} 5=(0,744186047 \times 0,4)+(0,516911295 \times 0,4)+(0,771795277 \times 0,2)=0,658797992$

$\mathrm{V} 6=(0,744186047 \times 0,4)+(0,534141672 \times 0,4)+(0,735416756 \times 0,2)=0,658414439$

$\mathrm{V} 7=(0,842105263 \times 0,4)+(0,482450542 \times 0,4)+(0,754795231 \times 0,2)=0,680781368$

$\mathrm{V} 8=(1 \times 0,4)+(0,61947306 \times 0,4)+(0,357321491 \times 0,2)=0,719253522$

$\mathrm{V} 9=(0,941176471 \times 0,4)+(0,534141672 \times 0,4)+(0,370010413 \times 0,2)=0,66412934$

$\mathrm{V} 10=(0,864864865 \times 0,4)+(0,426656942 \times 0,4)+(0,667671143 \times 0,2)=0,650142951$ 
Maka, keputusan akhir yang didapat menggunakan metode SAW pada perangkingan lokasi habitat kelinci yaitu A3 = TONGGOH3 = 0,962526673

\subsection{Diagram Alir (Flowchart)}

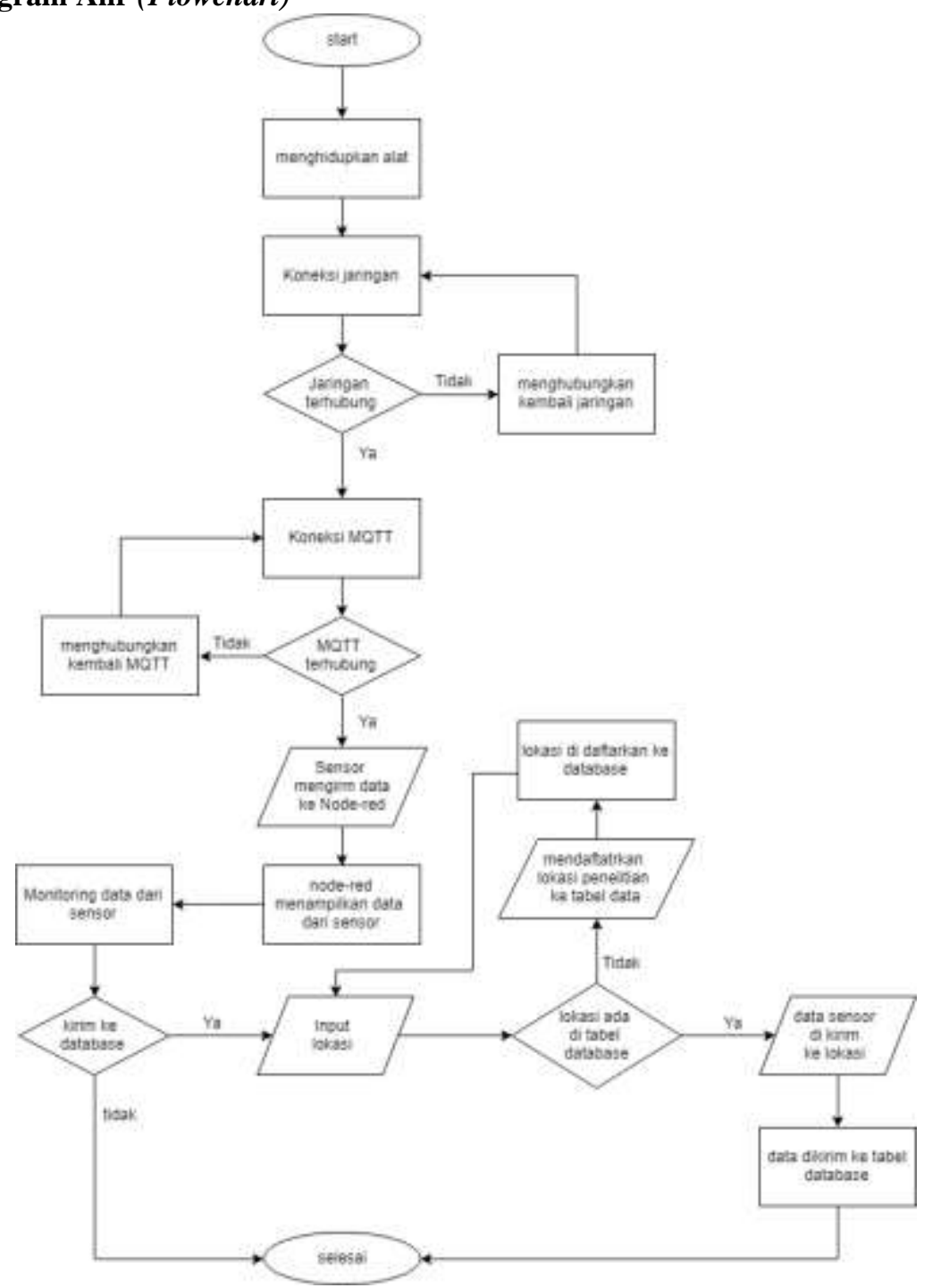

Gambar 3. 1 Diagram Alir (Flowchart)

Pada Gambar 3.1, Alat dihidupkan, kemudian alat terhubung dengan jaringan, jika jaringan tidak terhubung (tidak ditemukan) maka alat akan menghubungkan kembali ke jaringan sampai terhubung. Setelah alat terhubung ke jaringan maka alat akan menghubungkan ke MQTT Broker, setelah terhubung ke MQTT Broker maka data dari sensor di kirim ke node-red untuk ditampilkan di dashboard node-red. Jika data akan di kirim ke database, maka harus memasukkan id lokasi dari tempat penelitian, jika id lokasi tidak terdaftar pada database, maka user harus mendaftarkan terlebih dahulu data lokasi kemudian data dikirim ke database sesuai id lokasi yang di inputkan.

\subsection{Node-red Flow}

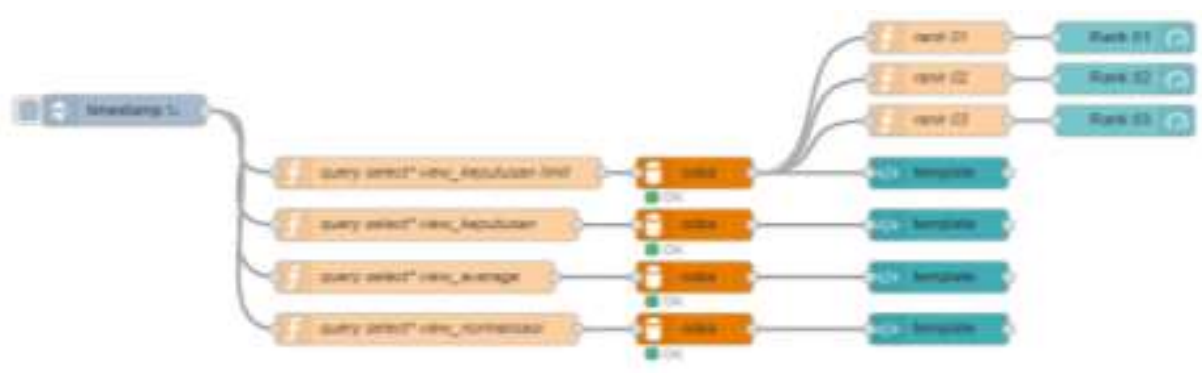




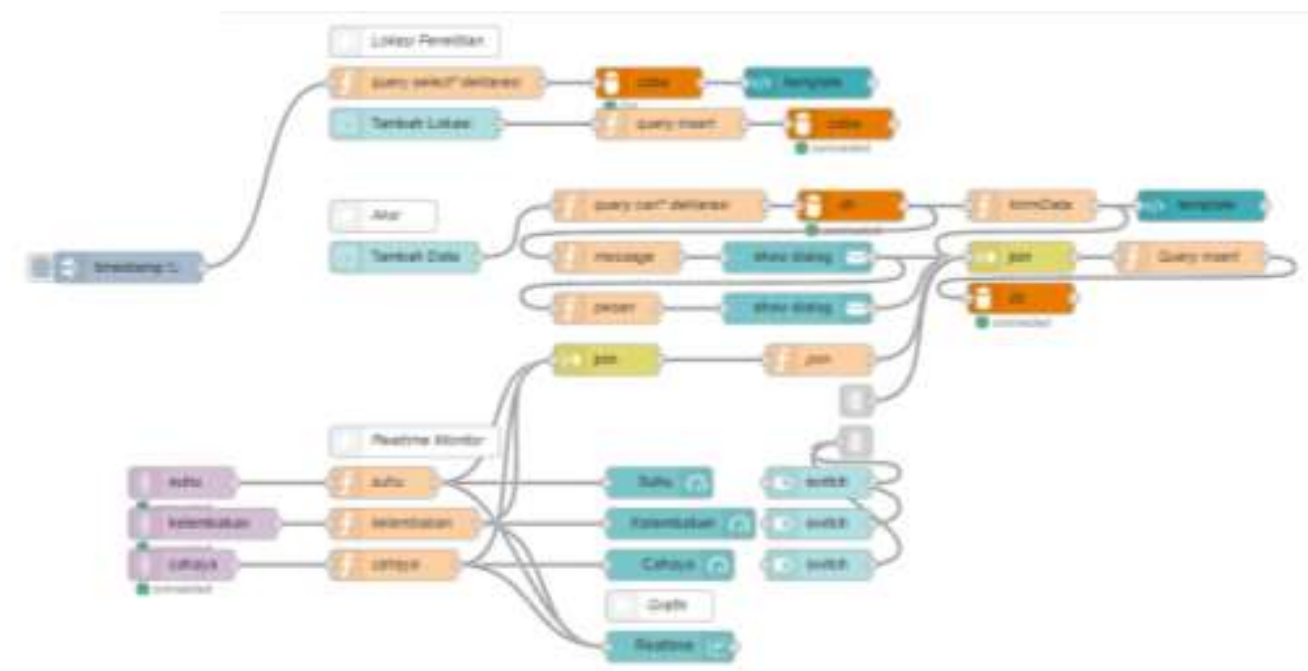

Gambar 3.2 Node-red Flow

Gambar 3.2 Node-red Flow, Flow pada grup lokasi penelitian merupakan flow yang digunakan untuk input data lokasi penelitian ke database. Flow aksi merupakan flow yang mana tugasnya ialah memasukkan data yang didapat dari sensor ke database. Flow Realtime Monitoring merupakan flow untuk menampilkan data dari sensor ke dashboard node-red. Flow grup paling bawah merupakan flow untuk menampilkan data hasil perhitungan metode SAW ke dashboard nodered.

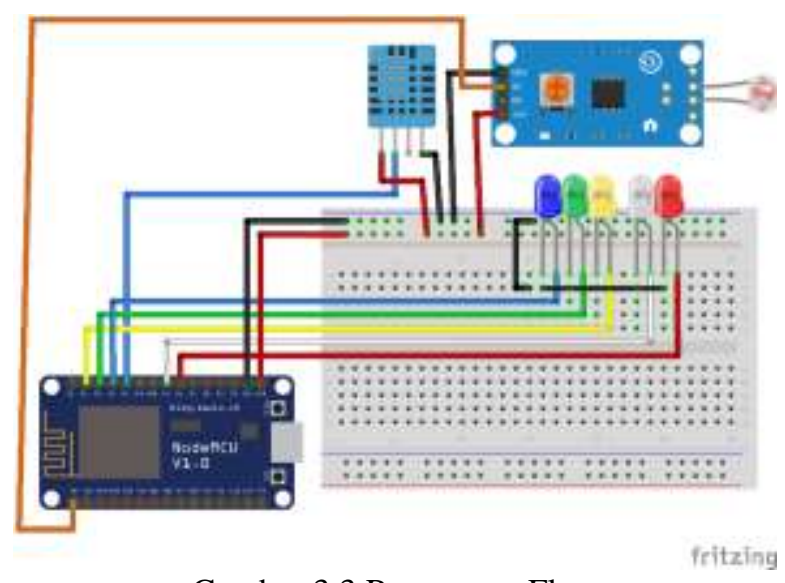

Gambar 3.3 Rancangan Flow

Berikut merupakan alat yang sudah dirakit berdasarkan rancangan yang sudah penulis buat sebelumnya.

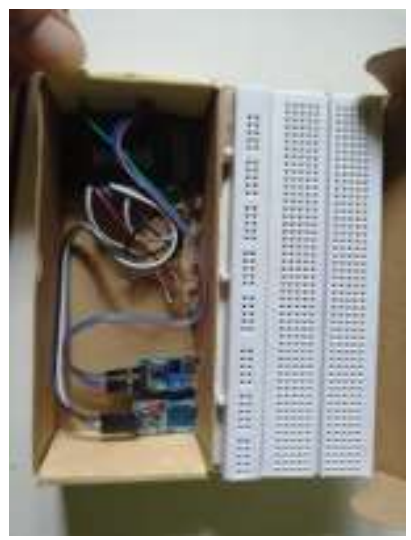

Gambar 3.4 Rancangan Prototype Alat Penelitian 


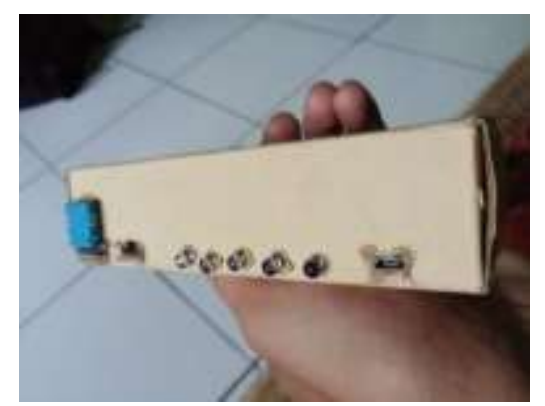

Gambar 3.5 Prototype alat

\section{Hasil}

\subsection{Node-Red Platform}

Implementasi antarmuka dibuat berdasarkan rancangan yang sudah ditentukan sebelumnya. Dalam penerapanya terdapat 2 halaman antarmuka yang bisa siakses oleh client maupun server, dan 2 halaman antarmuka yang hanya bisa diakses oleh server saja.

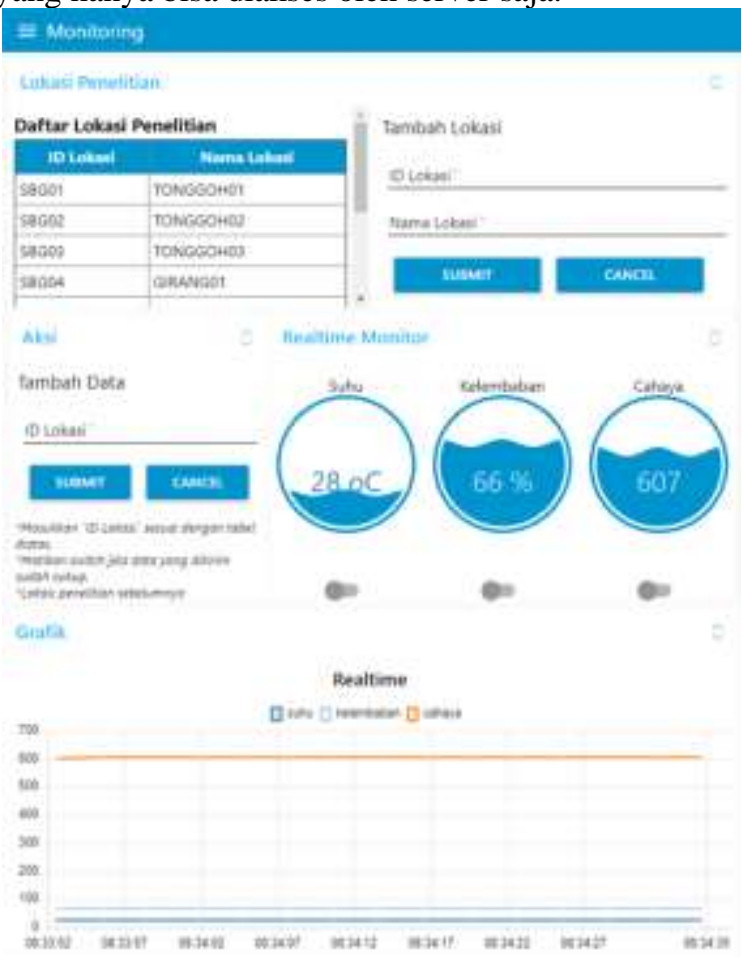

Gambar 4.1, Antarmuka monitoring 


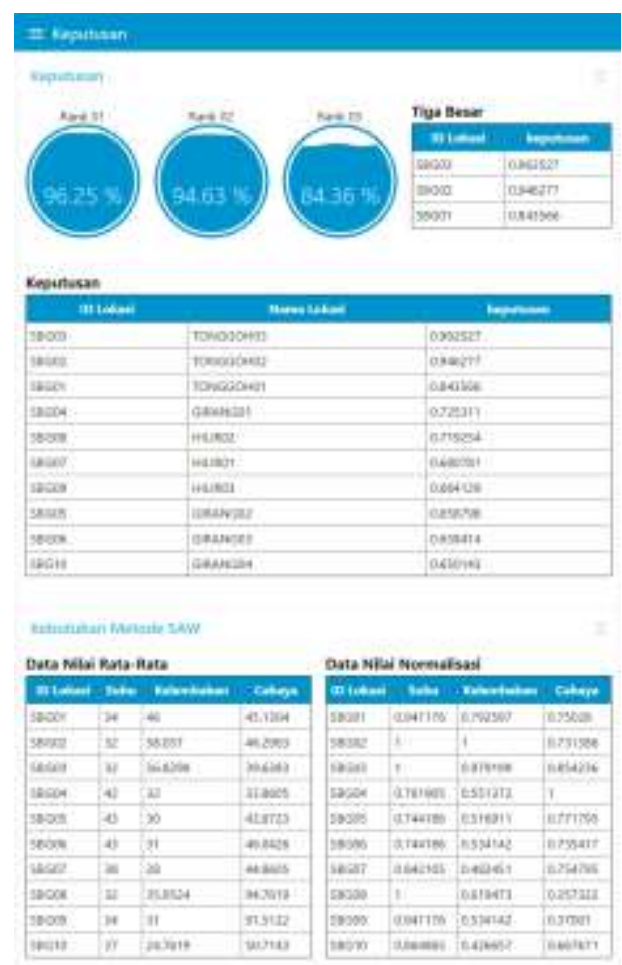

Gambar 4.2 Antarmuka Metode Perhitungan

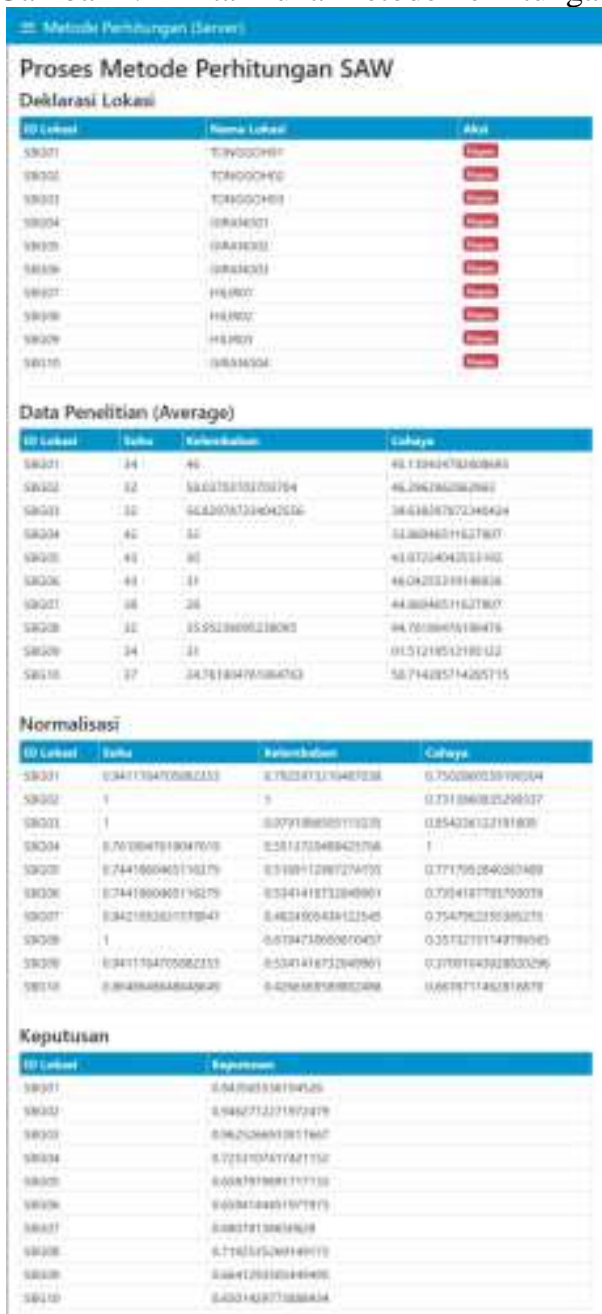

Gambar 4.3 Antarmuka Proses metode (server) 


\section{Kesimpulan}

Sistem ini dibangun dengan menggunakan komponen mikrokontroller yang berbasis IoT dengan menggunakan platform node-red, serta beberapa aplikasi bantuan seperti database mysql dan mqtt broker.

Dalam penelitian ini penulis mendapatkan beberapa kesimpulan, diantaranya:

1. Setelah melakukan penelitian ini penulis mendapatkan bahwa dengan adanya alat ini dapat mengurangi sedikit tingkat kegagalan dalam memelihara kelinci

2. Penelitian dilakukan dengan menggunakan metode perhitungan SAW yang mana metode ini digunakan untuk melakukan perangkingan sehingga hasil yang didapatkan adalah urutan lokasi yang paling direkomendasikan untuk dijadikan tempat tinggal kelinci.

\section{Daftar Pustaka}

[1] R. Hustamin, Paduan Memelihara Kelinci Hias. Jakarta: Agromedia Pustaka, 2006.

[2] T. P. Purnama, Temperatur Lingkungan Kelinci, Oktober 22, 2011. Accesed on: June 20, 2019. [online]. Available: https://rabbitries.wordpress.com/2011/10/22/temperaturlingkungan-kelinci/.

[3] Y. C. Rahardjo, B. Brahmantiyo, T. Murtisari, B. Wibowo, B. Juarini, and Yuniati, "Plasma Nutfah Kelinci sebagai Sumber Pangan Hewani dan Produk Lain Bermutu Tinggi”, Laporan Akhir Penelitian, Balai Penelitian Ternak, Badan Litbang Pertanian, Departemen Pertanian, 2004.

[4] F. Manshur, M. Fakkih, Kelinci Domestik: Perawatan dan Pengobatan. Penerbit Nuansa, Bandung, 2010.

[5] F. E. B. Hasibuan and B. J. Kolondam, "Interaksi Antara Mikrobiota Usus Dan Sistem Kekebalan Tubuh Manusia”, Jurnal Ilmiah Sains, vol.17, no.1, hal. 35-42, 2017.

[6] E. Turban, Decision Support System and Expert System, United State: Prentice Hall International, 1995.

[7] J. N. Usito, "Sistem Pendukung Keputusan Penilaian Proses Belajar Mengajar Menggunakan Metode Simple Additive Weighting (SAW)", Tesis, Program Studi Magister Sistem Informasi, Universitas Diponegoro, 2013.

[8] A. W. Burange, and H. D. Misalkar, "Review of Internet of Things in Development of Smart Cities with Data Management \& Privacy”, Ghaziabad, India: IEEE, 2015.

[9] Ariyanto, "Sistem Pendukung Keputusan Pemilihan Karyawan Terbaik Dengan Metode SAW (Simple Additive Weighting)", Skripsi, Fakultas Sains dan Teknologi, UIN Sunan Kalijaga, 2012.

[10] J. Simarmata, T. Limbong, M. Aritonang and S. Sriadhi, "Sistem Pendukung Keputusan Pemilihan Guru Bidang Studi Komputer Menggunakan Metode Simple Additive Weighting (SAW)", Computer Engineering, Science and System Journal, vol.3, no.2, hal. 186, 2018.

[11] D. A. Putri, "Penerapan Metode Fuzzy SAW Sebagai Pendukung Keputusan Pengangkatan Karyawan Tetap Perusahaan”, Techno Nusa Mandiri, vol.15 (2527-676X), hal. 31-36, 2018.

[12] S. Mulyono, M. Qomaruddin, and M. S. Anwar, "Penggunaan Node-RED pada Sistem Monitoring dan Kontrol Green House berbasis Protokol MQTT", Jurnal Transistor Elektro dan Informatika (Transistor EI), vol.3, no.1, hal 31-44, 2018.

[13] J. M. Tim, Develop with Node-RED, Retrieved from Intel Software Developer Zone: Mei 22, 2016. Accesed on: June 20, 2019. [online]. Available: https://software.intel.com/content/www/us/en/develop/documentation/gateway-gettingstarted-software-suite/top/connecting-to-cloud/connecting-to-microsoftazure.html?wapkw=node $\% 20$ red 